Indonesian Journal of Nutrition and Dietetics Vol. 6, Issue 1, 2018: 14-22
Available online at: http://ejournal.almaata.ac.id/index.php/IJND DOI : http://dx.doi.org/10.21927/ijnd.2018.6(1).14-22

\title{
Antidiabetic effect of Centella asiatica extract (whole plant) in streptozotocin nicotinamide-induced diabetic rats
}

\author{
Arwin Muhlishoh¹, Brian Wasita², Adi Magna Patriadi Nuhriawangsa ${ }^{3}$
}

'Department of Clinical Nutrition, Faculty of Pascasarjana Universitas Sebelas Maret

Jalan Ir. Sutami No. 36A, Jebres Surakarta 57126, Indonesia, Telephone (+62 271) 632450, Fax. (+62 271) 632450

${ }^{2}$ Department of Anatomical Pathology, Faculty of Health Sciences Universitas Sebelas Maret

Jalan Ir. Sutami No 36A, Jebres Surakarta 57126, Indonesia, Telephone (+62 271) 646994, Fax.(+62 271) 646655

${ }^{3}$ Department of Animal Husbandry, Faculty of Agriculture Universitas Sebelas Maret

Jalan Ir. Sutami No 36A, Jebres Surakarta 57126, Indonesia, Telephone (+62 271) 637457, Fax. (+62 271) 637457

${ }^{*}$ Corresponding author: arwin.muhlisoh@yahoo.com

\section{ABSTRAK}

Latar belakang: Pegagan telah digunakan untuk pengobatan diabetes mellitus. Namun dosis efek antidiabetes ini belum diteliti.

Tujuan: Untuk menguji pengaruh variasi dosis ekstrak pegagan (seluruh bagian tanaman) terhadap kadar gula darah, asupan makanan, dan berat badan pada tikus model diabetes mellitus yang diinduksi Streptozotocin Nicotinamide.

Metode: Tiga puluh enam tikus Wistar jantan dibagi menjadi enam kelompok perlakuan berbeda: kontrol negatif, kontrol positif, kontrol obat (metformin 45 mg/KgBB/hari), ekstrak pegagan 300 mg/KgBB/hari, 600 $\mathrm{mg} / \mathrm{KgBB} / \mathrm{hari}, 1200 \mathrm{mg} / \mathrm{KgBB} / \mathrm{hari}$. Pemberian ekstrak pegagan (seluruh bagian tanaman) dan metformin dilakukan selama28 hari. Kadargula darah dianalisis menggunakan Glucose Oxidase PhenolAminoantipyrina Peroxidase (GOD-PAP) sebelum dan sesudah perlakuan. Berat badan dan asupan makanan diukur setiap satu minggu. Data dianalisis menggunakan One Way ANOVA dengan tingkat kepercayaan 95\%. Hasil: Pemberian variasi dosis ekstrak pegagan dan metformin secara signifikan menurunkan kadar gula darah, meningkatkan berat badan dan memperbaiki asupan makanan $(p=0,00)$. Kadar gula darah dan asupan makanan pada kelompok ekstrak pegagan (seluruh bagian tanaman) dosis tinggi (1200 mg / KgBB / hari) lebih baik dibanding kelompok dosis rendah (300 mg / KgBB / hari) dan kelompok dosis sedang (600 $\mathrm{mg} /$ hari), dan memiliki efek yang sama dengan tikus yang diobati dengan metformin $45 \mathrm{mg} / \mathrm{KgBB} / \mathrm{hari}$. Kesimpulan: Dosis tinggi ekstrak pegagan (1200 mg/KgBB/hari) memiliki efek anti-diabetes yang lebih baik dibanding dosis lain, dan memiliki efek yang sama dengan kontrol obat.

KATA KUNCI: gula darah, diabetes, pegagan, Streptozotocin nicotinamide

\section{ABSTRACT}

Background: Centella asiatica has been used for healing diabetes mellitus. The dosage of this antidiabetic effect was yet to be explored.

Objectives: To examine the effect of the variation in the dosage of C. asiatica extract (whole plant) on blood glucose levels, food intake, and body weight in Streptozotocin Nicotinamide induced diabetic rats. Methods: Thirty-six male Wistar rat were divided into six different groups of treatments: negative control, positive control, medication control (metformin $45 \mathrm{mg} / \mathrm{KgBW} /$ day), extract of C. asiatica $300 \mathrm{mg} / \mathrm{KgBW} /$ day, $600 \mathrm{mg} / \mathrm{KgBW} /$ day, $1200 \mathrm{mg} / \mathrm{KgBW} /$ day. Treatments of C. asiatica extract (whole plant) and metformin was done for 28 days. Blood glucose was analyzed using the Glucose Oxidase Phenol Aminoantipyrina Peroxidase (GOD-PAP) before and after treatment. Body weight and food intake were measured every one week. The data were analyzed using One Way ANOVA with 95\% confidence level.

Results: The administration of the variation in the dosage of $C$. asiatica extract and metformin significantly decrease blood glucose levels, increase body weight and improve food intake $(p=0.00)$. Blood glucose level and food intake among high dosage of C. asiatica extract (whole plant) group (1200 mg/KgBW/day) is better than the low dosage group (300 mg/KgBW/day) and moderate dosage group (600 mg/KgBW/ 
day), and have the same effect with the rats treated with metformin $45 \mathrm{mg} / \mathrm{KgBW} /$ day.

Conclusion: High dosage of $C$. asiatica extract (1200 mg/KgBW/day) had a better anti-diabetic effect than other dosages, and had the same effect with the medication control.

KEYWORDS: blood glucose, Centella asiatica, diabetes, nicotinamide, Streptozotocin

\section{INTRODUCTION}

Diabetes Mellitus (DM) is a metabolic disorder that becomes the main problem of the health in all around the world, the prevalence in the world reaches the number of 382 million people and it is estimated to increase into 592 million people by 2035 , while in Indonesia the patients of DM increases from 1.1 percent (1.1\%) in 2007, to $2.1 \%$ in 2013 on the basic health research (IDF, 2014; Ministry of Health, 2013).

Type 2 Diabetes Mellitus (T2DM) is a complex metabolic disorder that is marked with the case of hyperglycemia as a result of the failure of cell $\beta$ pancreas so that there is a resistance for the insulin (3). T2DM happens because of the disturbance of the progressive insulin secretion that becomes the main problem of a resistance to the insulin (4). Severe hyperglycemia and the disturbance of the insulin secretion cause several indications such as polyuria, polydipsia, polyphagia, and the loss of weight $(5,6)$. Severe hyperglycemia that happens to T2DM patients may poison the cell $\beta$ pancreas with the glucose and the patients may have the apoptosis $(7,8)$.

The anti-diabetes oral therapy plays an important role in controlling the level of the blood glucose. However, some researchers show that the use of anti-diabetes therapy can cause several side effects such as nauseous, digestion disorder, and diarrhea. Furthermore, if the therapy is used in a long-term, it can cause the other side effects such as the deficiency of vitamin B12, and the raising of the risk of cancer (9-11).

There is a raising of the demand for the herb availability from the plants that have the characteristic of antioxidant and anti-diabetes. Centella asiatica has been used as a traditional medicine (herbal medicine) in Indonesia and Asian countries since hundreds of years ago (12). C. asiatica is one of the herbs that have the characteristic of antioxidant and anti-diabetes (13-15). C. asiatica contains a high level of antioxidant from the group of pentacyclic triterpenoids (asiatic acid, made classic acid, asiaticoside, and madecassoside) (16-19). The content of triterpenoid contained in $C$. asiatica is known to improve glucose response through increased protein GLUT4 muscle, IR, IRS 1, and IRS 2 (20-24).

The use of $C$. asiatica extract as the herb availability has more positive sides such as effective, relatively cheaper, low level of side effects, and low level of toxicity (20). The use of triterpene marker on the extract of $C$. asiatica is more effective to the T2D patients in increasing the secretion of the insulin compared to the antidiabetes oral medicine (21. 25-27). The use of Ethanol extract of the $C$. asiatica leaves, a dosage of $300 \mathrm{mg} / \mathrm{KgBW} /$ day for 28 days is proven in normalizing the level of blood glucose in Type 2 Diabetic Model Rats - the induction of high-fat diet and the Streptozotocin, but the use of the variation in the dosage $(300,600,1200 \mathrm{mg} / \mathrm{KgBW} /$ day) of ethanol extract from all parts of $C$. asiatica (roots, stems and leaves) to blood glucose levels, body weight and feed intake in the type 2 diabetic model rats-streptozotocin-nicotinamide (STZ$N A$ ) induced diabetic rats is unknown. Therefore, the aims of this study are to evaluate the effect of $C$. asiatica extract as anti-diabetic to blood glucose levels, body weight and feed intake in Streptozotocin-Nicotinamide (STZ-NA) induced diabetic rats.

\section{MATERIALS AND METHODS}

This study was experimental research with the randomized post-test only with controlled group design. The study was conducted from March to September 2017. The whole methods that were used had been approved by the Health Research Ethics Committee Dr. Moewardi General Hospital 
and School of Medicine, Universitas Sebelas Maret (128/II/HREC/2017).

The sample of $C$. asiatica was obtained from commercial products. C. asiatica was extracted with the ethanol of $70 \%$ (ChemPur, Karlsruhe, Germany) (28). T C. asiatica extract was made done at LPPTUnit 1 (Lembaga Penelitian dan Pengujian Terpadu) Universitas Gadjah Mada Yogyakarta - Unit 1.

Thirty six male albino Wistar rats (Rattus norvegicus) in the age of 8-10 weeks in the body weight of $200 \pm 50$ gram were divided into 6 different groups of treatments:

1. Negative control (standard feed- comfeed, aquades)

2. Positive control (standard feed- comfeed, aquades, STZ-NA)

3. Medication control (standard feed- comfeed, aquades, STZ-NA, metformin $45 \mathrm{mg} / \mathrm{KgBW} /$ day)

4. CAE treatment dosage 1 (standard feedcomfeed, aquades, STZ-NA, CAE $300 \mathrm{mg} /$ $\mathrm{KgBW} /$ day)

5. CAE treatment dosage 2 (standard feedcomfeed, aquades, STZ-NA, CAE $600 \mathrm{mg} /$ $\mathrm{KgBW} /$ day)

6. CAE treatment dosage 3 (standard feedcomfeed, aquades, STZ-NA, CAE $1200 \mathrm{mg} /$ $\mathrm{KgBW} /$ day)

Animal breeding was attempted based on the modification procedures by Nain et al. (2012) (29). Thirty six male Wistar rats were placed in a large hygienic polypropylene enclosure containing 6 insulated rats, filled with one rat per bulkhead. The rats were maintained in a room with a temperature control $\left(22 \pm 20^{\circ} \mathrm{C}\right) 12$ hours of bright light and 12 hours dark cycle (lights turned on at $07.00 \mathrm{am}$ ), humidity $70-90 \%$. The STZ-NA induction was performed on the modification of the Ortiz-Andrade et al. (2008) with a dosage of streptozotocin 65 $\mathrm{mg} / \mathrm{KgBW}$ and nicotinamide $230 \mathrm{mg} / \mathrm{KgBW}$, rats expressed hyperglycemia if the blood glucose level was $\geq 150 \mathrm{mg} / \mathrm{dL}$ (30).

The measurement of glucose blood levels using the Glucose Oxidase Phenol Aminoantipyrina Peroxidase (GOD-PAP) method using Glucose GOD FS kit from Diagnostic System International
(Diasys, Holzheim, Germany), was done before treatment and 28 days after the administration of C. asiatica extract. The measurements were made in the morning before feeding, blood samples were obtained from the orbital vein end. A total of \pm 0.5 $\mathrm{ml}$ of blood samples which were taken had been collected into Eppendorf, centrifuged for 10 minutes at $2500 \mathrm{rpm}$, the serum was taken and the enzymatic blood glucose levels were determined by GOD-PAP method (31).

Each rat was weighed by using digital scales and measured every seven days during the research. While the intake of feed in each week was calculated from the average total feed intake in one week (the feed gave minus the remaining feed) as measured using a digital scales. The maintenance and the manufacture of laboratory rats, the measurement of blood glucose levels, the body weight and the feed intake were done in Laboratorium Pusat Pangan dan Gizi PAU Universitas Gadjah Mada. The statistical analysis was performed using SPSS for Windows release 20.0. The data obtained were tested for normality using Shapiro-Wilk test and homogeneity using Levene's test. The data variant is normally distributed and homogeneous such as blood glucose levels and the body weight, it is followed by the OneWay ANOVA (Analysis of Varian) test to determine the average difference between the six groups, followed by the tukey high significant difference (HSD) test to identify the different groups of names significantly. The normality and homogeneity requirements of the data are not met such as feed intake, then a comparable nonparametric test is a Kruskal-Wallis test. If there are significant differences, it will be continued with the Mann-Whitney test. The differences in blood glucose levels, weight, and feed intake before and after the treatment in all groups were tested for paired t-test. There is a significant difference if $p$-value $<0.05$ (32).

\section{RESULTS}

\section{Centella asiatica extract reduced blood glucose levels in STZ-NA induced diabetic rats}

The analysis of blood glucose level before STZ-NA induction had a normal and homogeneous variation $(p>0.05)$. Measurement of rat blood 
glucose level was done 3 times: before induced STZ-NA, three days after induction of STZ-NA, and 28 days after treatment of $C$. asiatica extract dose 300,600 and $1200 \mathrm{mg} / \mathrm{kgBW} /$ day and metformin $45 \mathrm{mg} / \mathrm{KgBW} /$ day which can be seen in Table 1 .

The mean of the blood glucose levels before and after the treatment differed significantly $(p=0.00)$. Giving ethanol extract of $C$. asiatica in the dosage of $300 \mathrm{mg} / \mathrm{KgBW} /$ day (P1), $600 \mathrm{mg} / \mathrm{KgBW} /$ day (P2), $1200 \mathrm{mg} / \mathrm{KgBW} /$ day (P3) and metformin $45 \mathrm{mg} / \mathrm{KgBW} /$ day (MC) was proven to be able to decrease the rat's blood glucose levels significantly $(p=0.00)$. The result of the measurement of blood glucose level in the group treated with extract of C.asiatica in a dosage of $300 \mathrm{mg} / \mathrm{KgBW} /$ day (P1) showed that this treatment could decrease the blood glucose level significantly $(p=0.00)$ as much as $73.92 \pm 4.16 \mathrm{mg} / \mathrm{dL}$, but some rats still had the hyperglycemia (> $150 \mathrm{mg} / \mathrm{dL}$ ) (Table 1).

Blood glucose levels of rats which were treated with the extracts of $C$.asiatica in the dosage of $600 \mathrm{mg} / \mathrm{KgBW} /$ day decreased and did not have hyperglycemia, but this condition was not in the normal category. The normal blood glucose level of rats is $50-135 \mathrm{mg} / \mathrm{dL}$ (40). The results of Tukey HSD test showed a decrease in blood glucose level of rats treated with extract of C.asiatica $1200 \mathrm{mg} / \mathrm{KgBW} /$ day (P3), this was similar to the group that was given metformin $45 \mathrm{mg} / \mathrm{KgBW} /$ day (MC), and has reached the normal condition (Table 1). However, the effect of the decrease in the blood glucose level in the group with extract of C.asiatica $1200 \mathrm{mg} / \mathrm{KgBW} /$ day (P3) was $126.36 \pm 6.88 \mathrm{mg} / \mathrm{dL}$, better than the medication control group (metformin $45 \mathrm{mg} / \mathrm{Kg}$ of body weight) $120.70 \pm 6.65 \mathrm{mg} / \mathrm{dL}$ (Table 1).

\section{Centella asiatica extract improved food intake in STZ-NA induced diabetic rats}

The effect of the variation in the dosage of $C$. asiatica extract to food intake of rats can be seen in Table 2.

There was a significant change in the rats' feed intake before and after the treatment. However, based on Mann-Whitney's further tests, it was known that the intake of feed before the administration of C. asiatica extract in the negative control group, the positive control group, treatment dosage 1 , dosage 2 and dosage 3 were the same. While the medication

Table 1. Blood Glucose Level (mg/dl) before and after treatment

\begin{tabular}{lccc}
\hline \multicolumn{1}{c}{ Group } & $\begin{array}{c}\text { Pre test } \\
\text { (mg/dL) }\end{array}$ & $\begin{array}{c}\text { Post test } \\
\text { (mg/dL) }\end{array}$ & $\begin{array}{c}\text { Difference }(\boldsymbol{\Delta}) \\
(\mathbf{m g} / \mathbf{d L})\end{array}$ \\
\hline Negative control & $77.04 \pm 3.33^{\mathrm{a}}$ & $79.63 \pm 2.65^{\mathrm{a}}$ & $-2.59 \pm 1.29$ \\
Positive control & $256.83 \pm 7.27^{\mathrm{bc}}$ & $261.66 \pm 8.69^{\mathrm{b}}$ & $-4.83 \pm 2.42$ \\
Medication control & $253.28 \pm 6.28^{\mathrm{c}}$ & $132.58 \pm 4.10^{\mathrm{e}}$ & $120.70 \pm 6.65$ \\
CAE 300mg/KgBW (Dosage 1) & $261.78 \pm 4.58^{\mathrm{b}}$ & $187.86 \pm 1.89^{\mathrm{c}}$ & $73.92 \pm 4.16$ \\
CAE 600 mg/KgBW (Dosage 2) & $257.10 \pm 7.10^{\mathrm{bc}}$ & $143.35 \pm 2.23^{\mathrm{d}}$ & $113.75 \pm 7.44$ \\
CAE 1200 mg/KgBW (Dosage 3) & $257.56 \pm 5.69^{\mathrm{bc}}$ & $131.21 \pm 2.84^{\mathrm{e}}$ & $126.36 \pm 6.88$ \\
\hline
\end{tabular}

$\mathrm{n}=6$; CAE $=$ Centella asiatica extract; Delta $(\Delta)=$ the difference of average blood glucose levels before and after the treatment

a,b,c,d,e) Different notations indicated a significant difference based on the One-Way Anova test $(\mathrm{P}<0.05)$.

Tabel 2. Food intake (gram) before and after treatment

\begin{tabular}{lcc}
\hline \multicolumn{1}{c}{ Group } & $\begin{array}{c}\text { Pre test } \\
\text { (gram) }\end{array}$ & $\begin{array}{c}\text { Post test } \\
\text { (gram) }\end{array}$ \\
\hline Negative control & $12.67 \pm 1.03^{\mathrm{a}}$ & $13.17 \pm 0.75^{\mathrm{a}}$ \\
Positive control & $13.50 \pm 0.055^{\mathrm{a}}$ & $14.00 \pm 0.63^{\mathrm{b}}$ \\
Medication control & $12.33 \pm 0.52^{\mathrm{b}}$ & $12.33 \pm 0.78^{\mathrm{e}}$ \\
CAE 300mg/KgBW (Dosage 1) & $12.83 \pm 1.17^{\mathrm{a}}$ & $12.17 \pm 0.75^{\mathrm{c}}$ \\
$\mathrm{CAE} \mathrm{600} \mathrm{mg/KgBW} \mathrm{(Dosage} \mathrm{2)}$ & $12.83 \pm 0.41^{\mathrm{ab}}$ & $12.43 \pm 0.84^{\mathrm{d}}$ \\
CAE 1200 mg/KgBW (Dosage 3) & $13.17 \pm 0.75^{\mathrm{a}}$ & $13.00 \pm 0.89^{\mathrm{e}}$ \\
\hline
\end{tabular}

$\mathrm{n}=6$; $\mathrm{CAE}=$ Centella asiatica extract;

a,b,c,d,e $)$ Different notations indicated a significant difference based on the Kruskal Wallis test $(\mathrm{P}<0.05)$. 
control group was different from the other groups, but the same as the treatment group dosage 2. It can be seen that the polyphagia conditions that occur in rats have not been maximized. However, after 28 days there was an increase in feed intake in the positive control group and differed significantly with the other groups, as well as proving the presence of polyphagia conditions (Table 2).

The mean feed intake before and after the treatment differed significantly $(p<0.05)$. There was a significant decrease in intake of drug control rats, rats treated with extracts of $C$. asiatica dose 300 and $1200 \mathrm{mg} / \mathrm{KgBW} /$ day, but in rats given C. asiatica extract dose $600 \mathrm{mg} / \mathrm{KgBW} /$ day increased feed intake. There was a significant decrease in the intake of the same feed in the group of rats treated with $C$. asiatica extract in a dosage of $1200 \mathrm{mg} / \mathrm{KgBW} /$ day and given metformin of $45 \mathrm{mg} / \mathrm{BW} /$ day (Table 2).

\section{Centella asiatica extract increased body weight in STZ-NA induced diabetic rats}

The development of body weight was monitored periodically; before the induction of STZ-NA, 3 days after the induction and declared as DM type 2 which was the beginning of the treatment day-0, day-7, day-14, day-21, and day-28 after treatment (Figure 1).

The results showed that in the negative control group, healthy rats had significant weight gain in each week $(p<0.05)$. After the induction of STZ$\mathrm{NA}$, there was significant weight loss in the positive group, medication control group, and treatment group. This indicates that the induction of STZ-NA causes weight loss in rats. After the treatment,

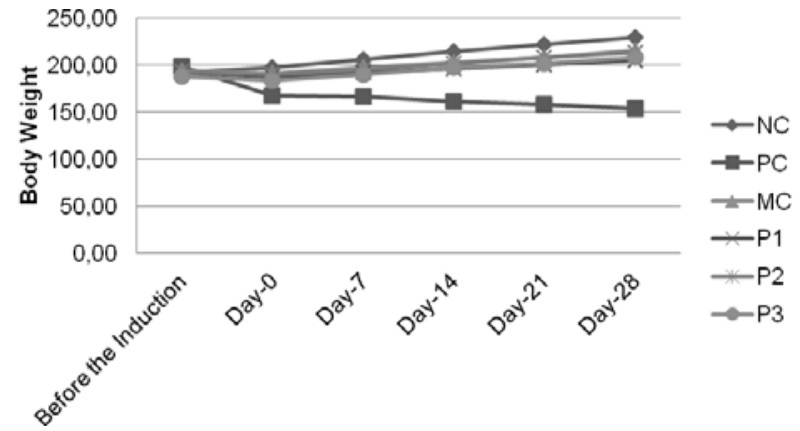

Figure. 1. The mean of body weight during 28 days

the experimental group of $C$.asiatica extract and medication control group had significant weight gain until the end of the study $(p<0.05)$. While in the positive control group, the group of untreated diabetic type 2 model rats experienced significant weight loss each week $(p=0.00)$.

The mean weight of rats after the treatment for 28 days of $C$. asiatica extract with $300 \mathrm{mg} / \mathrm{KgBW} /$ day with a dosage of $1200 \mathrm{mg} / \mathrm{KgBW} /$ day, a dosage of $600 \mathrm{mg} / \mathrm{KgBW} /$ day with metformin $45 \mathrm{mg} / \mathrm{KgBW} /$ day was the same as presented in Table 3 .

\section{DISCUSSION}

The laboratory rats experienced the hyperglycemia 3 days after the induction of Streptozotocin-Nicotinamide (STZ-NA) with the blood glucose level $>150 \mathrm{mg} / \mathrm{dL}$. There were no dead rats. This was due to the effect of Nicotinamide (NA) protection against excess cytotoxic $\beta$ effects of STZ so that until the research was complete there were no dead rats even on the rats with the positive control (33).

Table 3. Body weight (gram) before and after treatment

\begin{tabular}{lccc}
\hline \multicolumn{1}{c}{ Group } & $\begin{array}{c}\text { Pre test } \\
\text { (gram) }\end{array}$ & $\begin{array}{c}\text { Post test } \\
\text { (gram) }\end{array}$ & $\begin{array}{c}\text { Difference ( } \\
\text { (g) }\end{array}$ \\
\hline Negative control & $197.83 \pm 7.36^{\mathrm{a}}$ & $229.83 \pm 6.24^{\mathrm{a}}$ & $-32.00 \pm 1.79$ \\
Positive control & $195.17 \pm 6.82^{\mathrm{ab}}$ & $179.17 \pm 6.01^{\mathrm{b}}$ & $16.00 \pm 1.41$ \\
Medication control & $188.17 \pm 5.15^{\mathrm{b}}$ & $204.83 \pm 5.27^{\mathrm{c}}$ & $-16.67 \pm 0.52$ \\
CAE 300mg/KgBW (Dosage 1) & $189.67 \pm 2.88^{\mathrm{b}}$ & $213.83 \pm 2.48^{\mathrm{d}}$ & $-24.17 \pm 1.17$ \\
CAE 600 mg/KgBW (Dosage 2) & $187.17 \pm 2.32^{\mathrm{b}}$ & $207.83 \pm 2.40^{\mathrm{c}}$ & $-20.66 \pm 0.52$ \\
CAE 1200 mg/KgBW (Dosage 3) & $191.17 \pm 3.06^{\mathrm{b}}$ & $215.17 \pm 3.71^{\mathrm{d}}$ & $-24.00 \pm 0.89$ \\
\hline
\end{tabular}

$\mathrm{n}=6$; $\mathrm{CAE}=$ Centella asiatica extract; Delta $(\Delta)=$ the difference of average blood glucose levels before and after the treatment

$a, b, c, d, e)$ Different notations indicated a significant difference based on the One-Way ANOVA test $(p<0.05)$. 
The T2DM model rats were inducted by using Streptozotocin-Nicotinamide because it has several advantages: (1) stable moderate hyperglycemia that does not require exogenous insulin to survive; (2) decreased $\beta$-cell by $40 \%$ and decreased insulin production by $60 \%$ (3) glucose intolerance due to the impaired insulin secretion; (4) the presence of glucose-stimulated insulin secretion (though it was disturbed); and (6) weight loss, polyphagia and polydipsia (34). The giving of $C$. asiatica extract till the dosage of $1200 \mathrm{mg} / \mathrm{KgBW}$ for 28 days did not cause death in rats. This is in line with previous study in Rahman et al. (2012), the provision of $C$. asiatica extract up to a dosage of $3000 \mathrm{mg} / \mathrm{KgBW} /$ day in laboratory rats showed no signs of acute toxicity and death (35). Before the intake of $C$. asiatica extract was done (pretest), the mean of the blood glucose level of the treatment group that was given with $C$. asiatica extract was the same as the medication control group, and the positive control group (T2D control), but different from the negative control group $(p=0.00)$ (Table 1). It was proved that before the treatment was carried out in the group of $C$. asiatica extract treatment and medication control group experienced the same hyperglycemia condition, same as the condition in the positive control group, and the making of type 2 diabetic model rats was successfully performed. The increasing of blood glucose levels (hyperglycemia) in type 2 diabetes occurred due to the energy metabolic disturbances (glucose absorption, glucose utilization, and TCA cycles), the increasing of gluconeogenesis (the increasing of endogenous glucose production) and glycogenolysis (36).

The giving of $C$. asiatica extract dosage 300 $\mathrm{mg} / \mathrm{KgBW} /$ day could decrease the blood glucose level but couldn't reach the normal limit (>150 mg/ $\mathrm{dL}$ ) (Table 1). This was not in line with the research of Maulidani et al. (2016) which states that the use of $C$. asiatica extract in a dosage of $300 \mathrm{mg} / \mathrm{KgBW} /$ day for 28 days can normalize the blood glucose levels (37). The difference of the results of this study was possible because of the differences in the inductions that were given in the making of the T2D model rats, part of $C$. asiatica that was extracted and the origin of $C$.asiatica used. Part of $C$. asiatica that was extracted and the origin of C.asiatica (location and environmental condition of C.asiatica planted) is one of the factors that influence the quality and quantity of phenolic bioactive compounds and the C.asiatica's triterpenoid $(17,38,39)$.

The giving of $C$. asiatica extract dosage 1200 $\mathrm{mg} / \mathrm{KgBW} /$ day could decrease the blood glucose level equivalent to metformin. Centella asiatica is a herb that is used as a traditional medicine (herbal medicine) in Indonesia and Asian countries since hundreds of years ago (12). C.asiatica contains a variety of chemical components, but the most is the antioxidant component of the triterpenoid group. C.asiatica has higher antioxidant content (89\%) when it is compared to grape seed $(83 \%)$ and vitamin C $(88 \%)(11,41)$. The results of the phytochemical test showed that $C$.asiatica contains the antioxidant of $\beta$-carotene, $\beta$-sitosterol, cholesterol, camphor, kaempferol, stigmasterol, flavonoid saponin, and the largest are pentacyclic triterpenoid groups (asiatic acid, made classic acid, asiaticoside, and madecassoside) (16-19).

Triterpenoid contained in Centella asiatica is a compound that plays a role in lowering blood glucose levels by improving glucose response through increased protein GLUT4 muscle, IR, IRS 1 , and IRS 2 (20-24). Giving the C.asiatica extracts can restore changes in carbohydrate metabolism enzyme levels, prevent lipid peroxidation, increase antioxidant status, and increase fat metabolism enzymes, thus lowering blood glucose levels and increasing plasma insulin levels. $(21,25,27)$.

Based on Table 2, it was known that there was a significant change in the rats' feed intake before and after the treatment. Polyphagia in T2D occurs due to the insulin in the blood is not enough to enter the blood glucose into the cell as a source of energy, thus causing the body always feel hungry (4). The giving of $C$. asiatica extract dosage $1200 \mathrm{mg} /$ $\mathrm{KgBW} /$ day could decrease equivalent to metformin (Table 2). A decrease in feed intake may be due to $C$. asiatica extract improves the polyphagia condition and increases rat's leptin hormone. Leptin is a hormone involved in regulating weight, feed intake, and energy expenditure. Giving an ethanol extract of $C$. asiatica can decrease feed intake and 
increase weight in laboratory animals that have leptin deficiency (42).

Type 2 Diabetes Mellitus is a complex metabolic disorder that is marked with the case of hyperglycemia as a result of the failure of cell $\beta$ pancreas so that there is a resistance for the insulin (3). T2D happens because of the disturbance of the progressive insulin secretion that becomes the main problem of a resistance to the insulin (4). Insulin secretion disorders lead to weight loss $(5,6)$. The disturbance of insulin secretion causes the blood glucose disruption to enter the cells in the muscle and fat tissue so that the energy source is obtained from the splitting of stagnant energy that is reserved and from the fat tissue through glycogenolysis and lipolysis. The process of glycogenolysis and lipolysis that occur continuously causes the decrease of the mass of the muscle and fat tissue and leads to weight loss. (4).

The given of $C$. asiatica extract resulted in the same weight gain of rat's as metformin (Table 3). Weight gain occurs because $C$. asiatica extract has been shown to increase the levels of pyruvate, alanine, lactate, and crevice intermediate substances, leading to the increase of glycolysis, the decrease of gluconeogenesis and the increase of Kreb cycle' (34). The administration of $C$. asiatica extract in T2D model rats was significantly shown to restore the major enzyme activity in the increase of glycoses, such as hexokinase, glucose-6-phosphate dehydrogenase (G6PDH), and pyruvate kinase (PK) $(11,21)$.

\section{CONCLUSIONS AND RECOMMENDATIONS}

The extracts of $1200 \mathrm{mg} / \mathrm{KgBW} /$ day of Centella asiatica had a better antidiabetic effect than dosage 300 and $600 \mathrm{mg} / \mathrm{KgBW} /$ day, and had the same effect with metformin $45 \mathrm{mg} / \mathrm{KgBW} /$ day. A similar study needs to be done but with longer hyperglycemia conditions before the treatment, so that the signs and symptoms of type 2 diabetes in rats are more visible.

\section{REFERENCES}

1. International Diabetes Federation (IDF). IDF Diabetes Atlas. 6th ed. Brussels, Belgium: International Diabetes Federation; 2014.
2. Kementerian Kesehatan RI. Riset Kesehatan Dasar RISKESDAS 2013. Jakarta: Kementerian Kesehatan RI; 2013.

3. Montane J, Cadavez L, Novials A. Stress and the inflammatory process: A major cause of pancreatic cell death in type 2 diabetes. Diabetes, Metab Syndr Obes Targets Ther. 2014;7(February):25-34.

4. American Diabetes Association (ADA). Classification and Diagnosis of Diabetes. Diabetes Care. 2015; 38: 8-16.

5. Tjokroprawiro, A. IImu Penyakit Dalam. Surabaya: Airlangga University Press; 2007.

6. American Diabetes Association. "Diagnosis and Classification of Diabetes Mellitus". Diabetes Care. 2014; 37(1): s81-s90.

7. Anuradha R, Saraswati M, Kumar KG, Rani SH. Apoptosis of beta cells in diabetes mellitus. DNA Cell Biol [Internet]. 2014;33(11):743-8.

8. Tomita T. Apoptosis in pancreatic $\beta$-islet cells in Type 2 diabetes. Bosn J basic Med Sci. 2016;16(3):162-79.

9. Bodmer M, Meier C, Krahenbuhl S, Jick SS, Meier CR. Long-term metformin use is associated with decreased risk of breast cancer. Diabetes Care [Internet]. 2010;33(6):1304-8.

10. de Jager J, Kooy A, Lehert P, Wulffelé MG, van der Kolk J, Bets D, et al. Long term treatment with metformin in patients with type 2 diabetes and risk of vitamin B-12 deficiency: randomised placebo controlled trial. Bmj. 2010;340:c2181c2181.

11. Chong NJ, Aziz Z. A Systematic Review of the Efficacy of Centella asiatica for Improvement of the Signs and Symptoms of Chronic Venous Insufficiency. Evid Based Complement Altern Med [Internet]. 2013;2013:627182.

12. Kementerian Kesehatan RI. Vademekum Tanaman Obat Untuk Saitifikasi Jamu. Jilid 1. Jakarta: Kementerian Kesehatan RI; 2012.

13. Pumthong G, Nathason A, Tuseewan M, Pinthong $P$, Klangprapun $S$, Thepsuriyanon D, Kotta P. Complementary and Alternative Medicines for Diabetes Mellitus Management in Asean Countries. Complementary Therapi Medicines. 2015; vol. 23: 617-25. 
14. Dewi RT, Maryani F. Antioxidant and a-Glucosidase Inhibitory Compounds of Centella Asiatica. Procedia Chem [Internet]. 2015;17:147-52.

15. Mohamed NA, Abdou HM. The hypoglycemic and antioxidative effects of Centella asiatica against stz-induced diabetic disorders in rats. Int J Pharma Bio Sci. 2015;6(2):B621-33.

16. Subban R, Veerakumar A, Manimaran R, Hashim KM, Balachandran I. Two New Flavonoids from Centella asiatica (Linn.). Journal of Natural Medicines. 2008; 62 (3): 369-373.

17. James JT, Dubery IA. Pentacyclic Triterpenoids From The Medicinal Herb, Centella asiatica (L.). Molecules. 2009; 14 (10): 3922-3941.

18. Cao W, Li XQ, Zhang XN, Hou Y, Zeng AG, Xie $\mathrm{YH}$, Wang SW. Madecassoside Suppresses LPS-induced TNF-alpha Production In Cardiomycytes Through Inhibition of ERK, p. 38, and NF-kappaB Activity. International Immunopharmacology. 2010; 10 (7): 723-729.

19. Mustafa RA, Abdul HA, Mohamed S, Bakar FA. Total Phenolic Compounds, Flavonoids, and Radical Scavenging Activity of 21 Selected Tropical Plants. Journal of Food Science. 2010; 75 (1): C28-35.

20. Chauhan PK, Pandey IP, Dhatwalia VK, Singh $V$. Antidiabetic effect of ethanolic and methanolic leaves extract of centella asiatica on alloxan induced diabetic rats. Int J Pharm Bio Sci. 2010;1(1):1-6.

21. Ramachandran V, Saravanan R. Efficacy of asiatic acid, a pentacyclic triterpene on attenuating the key enzymes activities of carbohydrate metabolism in streptozotocininduced diabetic rats. Phytomedicine [Internet]. 2013;20(3-4):230-6.

22. Gayathri V, Lekshmi P, Padmanabhan RN. Anti-diabetes activity of ethanol extract of Centella asiatica ( $L$.) Urban (whole plant) in Streptozotocin-induced diabetic rats, isolation of an active fraction and toxicity evaluation of the extract. Int J Med Arom Plants. 2011;1(3):27886.

23. Ramachandran V, Saravanan R. Glucose uptake through translocation and activation of
GLUT4 in PI3K/Akt signaling pathway by asiatic acid in diabetic rats. Hum Exp Toxicol [Internet]. 2015;34(9):884-93.

24. Rahman S, Mostofa Jamal MAH, Parvin A, Mahfuz-Al-Mamun M, Rezuanul Islam M. Antidiabetic activity of centella asiatica (L.) urbana in alloxan induced type 1 diabetic model rats. J Bio-Science. 2011;19(1):23-7.

25. Ramachandran V, Saravanan R. Asiatic acid prevents lipid peroxidation and improves antioxidant status in rats with streptozotocininduced diabetes. J Funct Foods [Internet]. 2013;5(3):1077-87.

26. Nugroho AE, Lindawati NY, Herlyanti K, Widyastuti L, Pramono S. Anti-diabetic effect of a combination of andrographolide-enriched extract of andrographis paniculata (Burm f.) Nees and asiaticoside-enriched extract of Centella asiatica L. in high fructose-fat fed rats. Indian J Exp Biol. 2013;51(12):1101-8.

27. Ramachandran V, Saravanan R, Senthilraja P. Antidiabetic and antihyperlipidemic activity of asiatic acid in diabetic rats, role of HMG CoA: In vivo and in silico approaches. Phytomedicine [Internet]. 2014;21(3):225-32.

28. Pramono S, Ajiastuti D. Standardization of pegagan extract (Centella asiatica (L.) Urban) based on asiaticoside content using TLC- densitometric method. Majalah Farmasi Indonesia. 2004; 15( 3): 118-123

29. Nain P, Saini V, Sharma S, Nain J, Antidiabetic and Antioxidant Potential of Emblica Officinalis Gaertn. Leaves Extract in StreptozotocinInduced Type-2 Diabetes Mellitus (T2DM) Rats. Journal of Ethnopharmacology. 2012; 142: 65-71.

30. Ortiz-Andrade RR, Sanchez-Salgado JC, Navarrete-Vazquez G, Webster SP, Binnie M, Garcia-Jimenez S, Leon-Rivera I, CigarroaVazquez P, Villalobos-Molina R, Estrada-Soto $S$. Antidiabetic and toxicological evaluations of naringenin in normoglycaemic and NIDDM rat models and its implications on extra-pancreatic glucose regulation. Diabetes Obes. Metab. 2008; 10, 1097-1104. 
31. Subiyono, Martsiningsih, MA., Gabrela D. Gambaran Kadar Glukosa Darah Metode GOD-PAP (Glucose Oxsidase - Peroxidase Aminoantypirin) Sampel Serum dan Plasma EDTA (Ethylen Diamin Terta Acetat). Jurnal Teknologi Laboratorium. 2014; 5 (1): 45-48.

32. Sopiyudin DM. Statistik Untuk Kedokteran Dan Kesehatan. Jakarta: Salemba Medika; 2016.

33. Ghasemi A, Khalifi S, Jedi S. Streptozotocinnicotinamide-induced rat model of type 2 diabetes (Review). Acta Physiologica Hungaric. 2014; 101 (4): 408-420.

34. Masiello P. Animal models of type 2 diabetes with reduced pancreatic beta-cell mass. The International Journal of Biochemistry \& Cell Biology. 2006; 38: 873-893.

35. Rahman M, Sayeed MS Bin, Haque A, Hassan M, Islam SMA. Phytochemical screening, Antioxidant, Anti-Alzheimer and Anti-diabetic activities of Centella asiatica. J Nat Prod Plant Resourse. 2012;2(4):504-11.

36. Kumar V, Abbas AK, Aster JC. Robbins Basic Pathology. 9th edition. hiladelphia: Elsevier Saunders; 2013.

37. Maulidiani, Abas F, Khatib A, Perumal V, Suppaiah V, Ismail A, et al. Metabolic alteration in obese diabetes rats upon treatment with Centella asiatica extract. J Ethnopharmacol [Internet]. 2016;180:60-9.

38. Liyana-Pathirana C, Shahidi F. Optimization of Extraction of Phenolic Compounds From Wheat Using Response Surface Methodology. Food Chemistry. 2005; 93 (1): 47-56.

39. Rodrigues $S$, Pinto GAS, Fernandes FAN. Optimization of Ultrasound Extraction Of Phenolic Compounds From Coconut (Cocos Nucifera) Shell Powder By Response Surface Methodology. Ultrasonics Sonochemistry. 2008; 15 (1): 95-100.

40. Kusumawati D. Bersahabat dengan Hewan Coba, Yogyakarta: Gadjah Mada University Pres; 2004.

41. Hashim P, Sidek H, Helan MHM, Sabery A, Palanisamy UD, llham M. Triterpene composition and bioactivities of centella asiatica. Molecules. 2011;16(2):1310-22.

42. Bhat GK, Sea TL, Olatinwo MO, Simorangkir $D$, Ford GD, Ford BD, Mann DR. Influence of a leptin deficiency on testicular morphology, germ cell apoptosis, and expression levels of apoptosis related genes in the mouse. J Androl. 2006;27(2):302-310. 